\title{
The Prospect of Accountability in Local Governance in Nepal
}

\author{
Hari P. Dhungana
}

Email: hari@nou.edu.np

Accepted: 12 December 2018

Government accountability is intrinsic to democracies, as citizens can choose public officials through their popular vote and accordingly exercise some control and oversight over the officials. But elections held in periodic intervals do not allow the scrutiny of the decisions and activities that are conducted on a daily basis. This article examines how to confront this challenge of holding the governments to account, by looking into local governance in Nepal, where citizens have limited knowledge of the government decisions, activities, procedures followed, and their outcomes. This article is developed from the review of policies and laws and semi-structured interviews with elected leaders, civil service personnel, and other stakeholders in select local governments in Nepal. It argues that accountability in local government requires attention not only to laws, but also the practices of civic interaction and the willingness of elected officials and citizens in these engagements. It starts by establishing how the country's new Constitution of Nepal (2015) espouses a local social contract in view of its division of jurisdictions. It then identifies and analyses the main approaches and tools on government accountability. These encompass broad constitutional provisions to specific legal, institutional and technocratic measures to hold officials to account. It then reveals recent local level experiences around the use of accountability tools and shows that the legacy of widespread collusion and misuse of power continues to be a bottleneck. It concludes that there is a need to foster greater civic demands on accountability and foster measures for deliberation at the municipal level on a more regular basis. Overall, local government accountability should be envisioned as a work-in-progress pursuit and should be coupled with systems of local planning and implementation and vitalization of local democracy.

Keywords: Local governance, accountability, transparency, federalism, Nepal

\section{Introduction}

Government accountability is intrinsic to democracies, as citizens can choose public officials through their popular vote and accordingly exercise some control and oversight over the officials. But elections held in periodic intervals do not allow the scrutiny of the decisions and activities that are conducted on a daily basis. This article examines how to confront this challenge of holding the governments to account, by looking into local governance in Nepal, where citizens have limited knowledge of the government decisions, activities, procedures followed, and their outcomes.

The demand for accountability implicitly started in 1940s with the struggles for the overthrow of hereditary Rana regime and for the establishment of democratic rule. While some degree of accountability in regard to the provision of public goods and services can be achieved in autocracies (Tsai, 2007), the notion is more broadly associated with the institutionalization of democratic rule (e.g. Taylor-Robinson, 2010; Herbert \& Wilkinson, 2007; Goetz \& Jenkins, 2005). Accordingly, the commitment of the Nepalese state to the ideal and practice of accountability received broad momentum after the restoration of democracy in 1990 in particular reference to the agenda on good governance. At the same time, the promulgation of the new constitution in Nepal in 2015 and the completion of the election for representative 
assemblies and governments at the local, provincial and federal levels have revived hopes for the bringing the country into the track of democratic evolvement. The restoration of constitutional order and establishment of elected institutions in 2017 offer a new window of opportunity. Firstly, it allows the elected politicians to pursue governance measures in order to be able to deliver on their election commitments for development and prosperity. Secondly, it also provides the opportunity to adapt the measures already undertaken under the rubric of good governance, accountability or related themes.

At the same time, the idea of accountability also entails a broader society-wide culture shaping the relationship between the citizens and the government (Niti, 2012). Such a culture has to do with the institutionalization of the relationship in which those with entrusted power and authority feel obligated to the right-holders, while the latter feel to be empowered to make demands on the former. The idea is therefore a linchpin of constitutional democracy, wherein the people exercise their powers for proper vigilance over their government for a larger social good. More specifically, the idea also envisages that citizens are able to create pressure on public officials to deliver public goods and services (Tsai, 2007). Accordingly, the promotion of government accountability helps consolidate and deepen democracy by norming the relationship between the people and the government and create pressures on the government to deliver public services better.

\section{Objectives of this paper}

Given the above context, this paper aims at articulating how local governments in Nepal establish and institutionalize accountability. More specifically, it develop accountability relationships in which local government are embedded, by employing the idea of "local" social contract in light of the constitutional sharing of power between the federal, provincial and local levels; understand the political commitment and revisit the policy, legal and institutional measures on local government accountability and their manifestations in local government settings; reflect on recent practices on local government planning and accountability as well as expectations for change received though the consultation with elected officials, civil service staff, and other local leaders.

\section{Methods}

This article is developed from two principal sources: review of legislative framework and accountability practice; semi-structured consultations with local government leaders and other actors in five local government jurisdictions. This work started with the review of Nepal's new constitution and emerging legal framework, and of the policy and institutional measures and experience on good governance and accountability. The review also included the experience on the use of social accountability.

Then consultation meetings were held with local government leaders and other actors at the local governments in five of the country's seven provinces (Table 1). In each province, either a Municipality or a Rural Municipality was chosen as a case study site, and consultations were held with a) elected political leaders, including Mayor/Chairperson, Deputy Mayor/Deputy Chairperson, ward chairs, ward members, women members, Dalit members, as well as local executive members, b) other political leaders, who were not elected, c) civil service personnel, including the chief administrative officer (CAO), accounts personnel, or technical staff, d) civil society people, e.g. journalists, NGO personnel, or local people. During 
this field consultation, the team employed a check-list and held the consultation in a conversational and open-ended manner.

Table 1: Case study municipalities and village municipalities

\begin{tabular}{|c|c|c|c|c|c|}
\hline & $\begin{array}{l}\text { Province } 2 \\
\text { Ganeshman } \\
\text { Charnath } \\
\text { Municipality }\end{array}$ & $\begin{array}{l}\text { Province } 3 \\
\text { Sunkoshi } \\
\text { Rural } \\
\text { Municipality }\end{array}$ & $\begin{array}{l}\text { Province } 4 \\
\text { Waling } \\
\text { Municipality }\end{array}$ & $\begin{array}{l}\text { Province } 5 \\
\text { Lamahi } \\
\text { Municipality }\end{array}$ & $\begin{array}{l}\text { Province } 6 \\
\text { Gurans Rural } \\
\text { Municipality }\end{array}$ \\
\hline Head & FSF-N & CPN-MC & $\mathrm{NC}$ & CPN-UML & $\mathrm{NC}$ \\
\hline $\begin{array}{l}\text { Deputy } \\
\text { Head }\end{array}$ & UCPN-M & CPN-MC & $\mathrm{NC}$ & $\mathrm{NC}$ & $\mathrm{NC}$ \\
\hline $\begin{array}{l}\text { Wards } \\
\text { Total }\end{array}$ & 11 & 7 & 14 & 9 & 8 \\
\hline
\end{tabular}

The choice of local government "sites" involved consideration of leadership of different parties, representation of rural and municipal areas, and social differences corresponding to the country's different geographies, mainly the Hills and Terai districts. The sites were not meant to be statistically representative, but the selection tried to capture diversity pertaining to leadership from different parties, Hills/Terai difference, local cultural factors, rural/urban contexts. The local governments also differed in local power structure established from the local election of 2017 (e.g. whether Mayors had a "majority rule" or were outnumbered by representatives from other parties) and on the nature and intensity of conflicts and contestation arising from such structure.

\section{Local social contract: local government powers and the covenant}

In articulating accountability in Nepal's local governance, it is necessary to articulate the power sharing arrangement established by the new Constitution of Nepal and the nature of social contract or covenant. Unlike in most notable of other federations in the world, Nepal's federal model recognizes local government as part of the constitutionally recognized and largely autonomous polities. This shifts onus of delivering several of constitutional obligations (for example, fundamental rights) to local governments. As a corollary, it requires the local governments to operate with democratic, accountable and transparent manner - the principles that are enshrined in the new constitution, and several of previous laws. More than that, the new constitution also premises upon a unique relationship of local government with the people, which we prefer to call a retrofitted "local social contract," which will evolve into a set of shared mutual expectations and obligations as accountability relationships between them.

As a clear manifestation of this, the budget speech for the fiscal year 2017/18 announced, for the first time in the history of Nepal, a separate allocation as "inter-governmental fiscal transfers" to the local governments. Through this budget, the country's 753 local governments - which comprise Municipalities and Village Municipalities - received a total of 225 billion Rupees (USD 2.25 billion). It was not only unprecedented in the amount available to local governments, but also in terms of the share of national budget. It represented 17.6 percent of overall budget. The inter-governmental transfer initiated in 2017 is indicative of a broader 
constitutional change that has reshaped the working of the Nepalese state, its obligations, and its relationship with the people. The new local governments serve as both governments and as service providers, exercising jurisdictions pursuant to exclusive and concurrent powers enshrined in the constitution. In sum, local governments in Nepal will have to take charge of the following two jurisdictions:

a. Exclusive powers. Exclusive jurisdiction of powers and responsibility assigned to local government according to Annex 8 of the Constitution of Nepal

b. Concurrent powers. The jurisdictions of powers and responsibility shared with the provincial and federal government according to Annex 9 of the Constitution. These powers need to be acknowledged and assigned through legislative and financing measures at all three tiers of government.

In addition, local governments may in due course be assigned with additional decentralized powers. These are not currently established but may be established through policy and legislative measures from federal or provincial government when the latter consider it appropriate to decentralize or devolve certain powers within their jurisdictions. With the above powers at hand, local governments in Nepal are soon positioned to evolve as avenues for the exercise of powers and authority that encompass legislative, executive and limited range of judicial roles within their jurisdictions. While one anticipates a long and protracted power tussle between different tiers of the government, most of the powers of the local government are constitutionally established and cannot too easily be taken away. Accordingly, the local governments and the elected leaders as well as civil service working in them have now a huge responsibility to be serving as key actors to service the constitutional obligations (including several "fundamental rights"), and the directive principles that define a normative basis of how the governments should be working.

A major implication of this power is that local governments in the new set up will operate mainly pursuant to the constitution, rather than working under the directives of central level (now federal) ministry. This prompts the idea of "local" social contract, or covenant. This is because the local governments have autonomous and exclusive powers, and accordingly they represent a micro-state on their own, conceived as having had their own "local" social contract with the local population. An implication is that they will be expected to be accountable to people in a direct manner, in addition to accountability obligations to constitutionally designed institutions.

In constitutional terms, the local governments in Nepal are very unique vis-à-vis the federal and provincial governments. It is unique in that Nepal's local governments are autonomous and constitutionally recognized; while in many other federal countries they are placed sub-ordinate to provinces or states. In fact, they are sub-ordinate to none, except the constitution itself. In local governments, the executive head is elected directly from the people, and cannot be removed with a vote of no-confidence or with any notion of impeachment. Owing to the expansive political space, local governments may also be expected to uphold to the principles of good governance, such as separation of power, space for opposition and dissent, and accountability and transparency, as these are generally-held conditions to a constitutional democracy. 
Accordingly, local governments can be conceived in terms of their direct "social contract" relationship with local people, and in constitutional relationship with other levels of government and the constitutional bodies (Figure 1). It shows, first, that the local government leaders are now directly accountable to the people, and to the public oversight agencies. This is a very important departure from the past experiment with decentralization in Nepal.

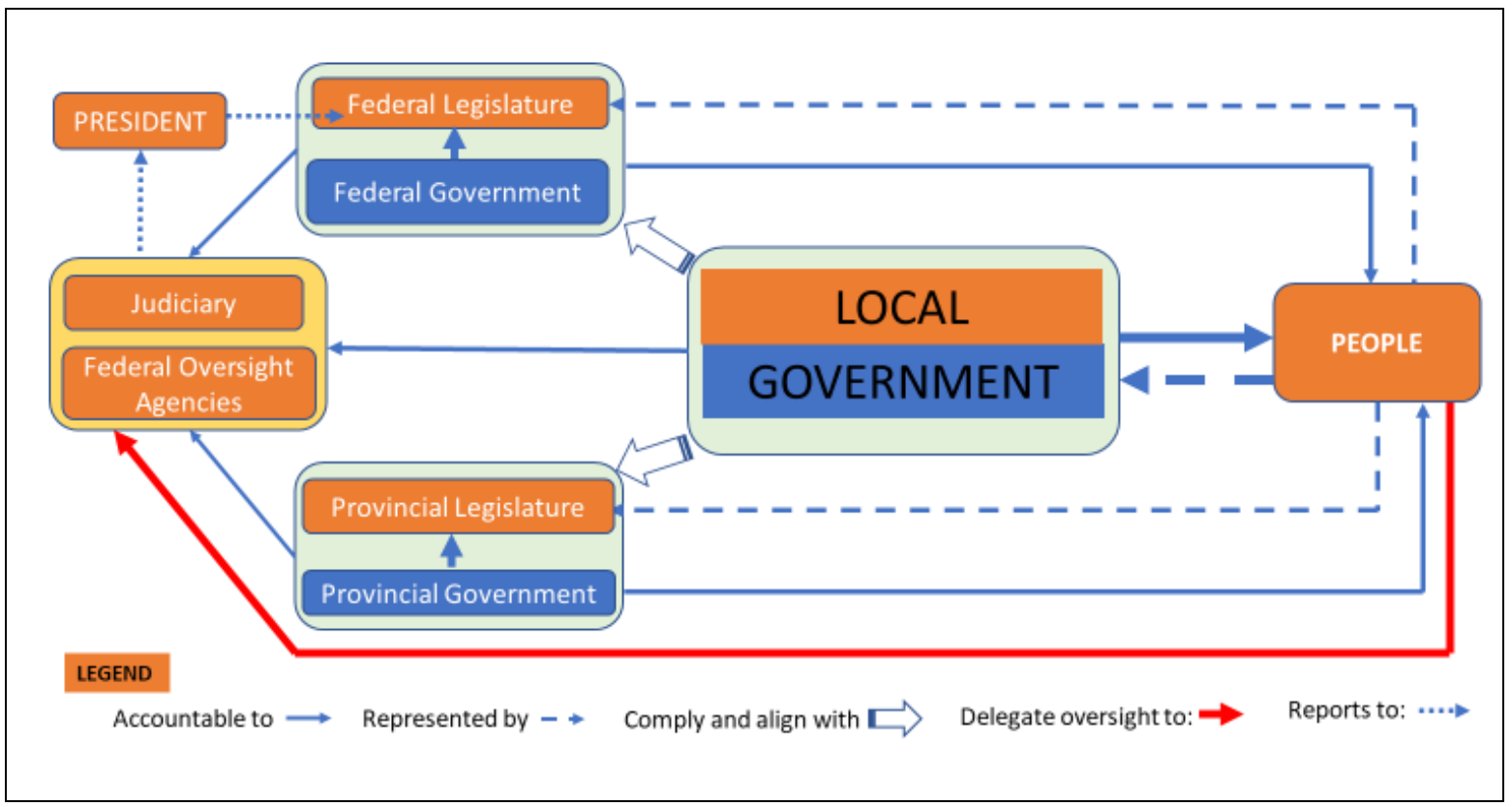

Figure 1: constitutional basis of accountability - key relationships around local government

Secondly, being directly accountable to people and becoming autonomous at least in regard to exclusive functions or jurisdictions implies that they enter into a form of local social contract or covenant with the local population. Such a covenant serves as a political basis of the relationship between the people and local governments and establishes mutual expectation and obligations between them. In its basic formulation, the relationship recognizes the people as "principals," who by virtue of their constitutionally recognized rights are entitled to check their "agents" - that is, the elected leaders and other public officials.

Under this sub-national self-rule, the local governments are not accountable to federal or provincial governments, except for the fact that they will comply and align with the general policies and programs from federal or provincial governments. Certain powers to enact laws have been vested to federal or provincial governments - they possibly represent "framework powers" and ideally will be less likely to be too specific to guide the actual behavior of the local governments over the long run.

Another distinctive feature of local government is that the local assembly and local executive are intricately enmeshed together-drawing in the assembly and executive members from different political parties, with Mayors or chairpersons being in minority, for example. Similarly, there are no formal "opposition parties" in the local government set up, even though

\footnotetext{
${ }^{1}$ Unlike in the Basic Law of Germany, Article 75, "framework powers" are not specifically mentioned in Nepal' constitution.
} 
elected leaders in many instances behave as per majority or minority feeling, pursuant to their power in making decisions. Thus, the overall ethos of governing in the local assembly and executive, therefore, is be of collaborative and participative nature. In addition, as there are limited legislative oversight/control over local executives. Therefore, holding the local executives politically accountable needs a recourse to the promotion of transparency, participation, and deliberation in local government decision-making.

\section{Main approaches to accountable governance}

By explicating the constitutional basis for the local social contract established above, this section moves to outline main approaches being adopted in Nepal for accountable governance. Primarily, accountability needs to be considered in reference to performance, finance and fairness (Niti 2012). That is to say, relevant questions for posing to local governments as well as individual officials are whether they performed well, how they handled public finance, and whether their decisions are consistent with perceptions or any standards of fairness and equity. The paragraphs below identify the approaches currently available and under development in regard to inculcating government accountability.

\section{Constitutional and political framework}

\section{Political approach}

The most prominent of the political framework for accountability comprises the right of Nepali citizens to provide a collective verdict in the election of representatives. Second, Nepal's constitution also provides as fundamental rights the rights to communication (Article 19) and right to information (Article 27) which provide a sound basis for demanding information from public officials and for largely uncensored or unrestrained communication of ideas or concerns. Thirdly, the constitution also upholds principles of the separation of powers and of checks and balances between different branches of the Nepalese state. Similarly, the federal parliament has established ten parliamentary committees to provide the oversight of the Members of the House of Representatives over the Executive and also to review and act upon the recommendations of constitutional oversight bodies. Of these committees, the Public Accounts Committee (PAC) is particularly prominent in regard to the oversight over public finances.

As former Speaker put it during the proclamation of the constitution in 2015, "A good constitution in itself isn't sufficient; wisdom and political maturity of leaders are key ingredients for success" (Bhattarai, 2015). Indeed, it is necessary to inculcate amongst local (as well as federal and provincial) government leaders the systems that ensure the judicious use of office powers with institutional and personal integrity.

\section{Judicial system}

Nepal's constitution commits in its Preamble to an "impartial, independent and competent" judiciary for the dispensation of justice. The judiciary is organized as a unitary arrangement, with the provision of Supreme Court, High Court, and District Court. The Supreme Court has a Constitutional Bench which looks into inter-governmental jurisdictional disputes. The court also has a provision for "Judicial Committee" headed by the Deputy Mayor or Vice Chairperson of local governments in order to settle or mediate certain enumerated disputes of local people. 


\section{Oversight through constitutional bodies}

An important provision in the constitution is the provision of constitutional bodies - primarily the Commission for the Investigation of Abuse of Authority (CIAA) and Auditor General -that have important functions in the oversight of public agencies in Nepal. These bodies, along with others, ${ }^{2}$ are envisaged as entities delegated by the sovereign people to look into the working of the executive. The report from these commissions are received by the President of Nepal and passed on to the Parliament for their satisfaction as people's representatives. As shown in Figure 1, all levels of governments are accountable to these oversight agencies. However, for these constitutional bodies and for the judiciary, it is of paramount importance that they operate in an independent manner, with utmost personal and institutional integrity, and in professional manner. As has been noted:

"...in most systems of government, the task of holding accountable those to whom power has been delegated is itself delegated [...] to a relatively small number of individuals: senior judges, auditors-general, members of legislative public accounts committees. The question of who will watch the watchdog is as old as it is unavoidable. (Goez and Jenkins, 2005: p.1)

Indeed, it has been noted in several instances that the judiciary and the constitutional bodies have not fully lived up to credibility and public trust expected of their mandate. Despite constitutional and legal arrangement for their independence, several episodes of dubious behavior in these oversight institutions have already become public (Thapa, 2017). Accordingly, efforts at restoring their credibility and public trust will be essential, by ensuring ethical and professional integrity.

\section{Legal instruments}

The government of Nepal had taken various policy, legal and institutional measures for government accountability. A number of legislations are already in place, such as the Good Governance Act, or the Right to Information Act, as well as regulations and procedures. The country also has institutional mechanisms such as the Commission for the Investigation of Abuse of Authority (CIAA), and other constitutional bodies, and legislative oversight entities. In addition, a number of executive agencies such as the National Vigilance Centre (NVC) or the Public Procurement Monitoring Office (PPMO) have been created to ensure direct vigilance and monitoring from the Prime Minister's Office. Furthermore, a number of social accountability tools are also being used at the local level by local governments and development agencies. These legal-institutional foundations and the experience gained from them comprise crucial resources for further work on government accountability.

At present, Nepal's new constitution and Local Government Operation Act 2017 (LGOA) are key legal documents that shape the accountability system of local government in the new constitutional order. However, other set of laws, such as those pertaining to public

\footnotetext{
${ }^{2}$ Other constitutional bodies in the constitution include Tharu Commission, Madhesi Commission, Women's Commission, Inclusion Commission, National Dalit Commission. Specific mandates of these commissions are not explicitly outlined in the constitution, but will most likely focus on the basic equality rights, dignity, entitlement and equity or social justice claims of these specific groups.
} 
oversight agencies such as the Commission of Investigation of Abuse of Authority (CIAA), control of corruption, public procurement, and provisions on right to information and for good governance in general. These set procedures, allocate responsibilities and create institutions for greater transparency, creating fairness in public procurement, adopting accountability tools, and reporting and disclosure requirements. Among the many laws, -CIAA Act 1991, financial procedures act 1999, audit act 1991, public procurement act 2007, right to information act 2007 and good governance act 2007 are main legal arrangements on governmental accountability. These laws were formulated before the promulgation of new constitution in 2015. The following are the prominent ones which relate to local government accountability.

Intergovernmental Fiscal Arrangement Act 2018: mainly concerned with fiscal discipline across levels of government.

National Natural Resource and Fiscal Commission Act 2017: mainly concerned with the establishment of the commission, setting its terms, and the broad principles of resource sharing.

Local Government Operation Act 2017: mainly concerned with the allocation and unbundling of functions for local governments and prescribing the legislative, executive and judicial business for the local level.

A detailed discussion on the legal aspects of accountability, however, is beyond the scope of this article.

\section{Executive surveillance, performance reviews and financial accountability}

\section{Executive surveillance and monitoring}

The other approach to accountability established in Nepal comprises the system for the surveillance and monitoring from executive branch from within a Federal Ministry or the Office of the Prime Minister and Council of Ministers (OPMCM). Prominent examples of these agencies include Department of Revenue Investigation (DRI), National Vigilance Center (NVC) and the Public Procurement Monitoring Office (PPMO). These have specific mandates for a prompt detection and action on such matters, respectively, as controlling the leakage of revenue, gathering evidence on irregularities or delays in public agencies, or ensuring good governance in the public procurement system.

\section{Performance review and evaluation}

Another approach to accountability in Nepal that is emerging relatively recently is the agencification for performance review or evaluation of projects, programs and policies. Such reviews are meant to provide evidence on whether specific projects, programs or policies performed well, achieved their intended impacts, or operated with a set of criteria such as relevance, efficiency, equity, or sustainability. A prominent example of agencification for performance reviews comprises the establishment in 2010 of Education Review Office (ERO), which is mandated to assess the performance in school education in terms of learning achievement. In addition, the National Planning Commission has a Monitoring and Evaluation Division, and it commissions independent evaluation of projects. Most ministries and 
departments of M\&E sections, yet performance reviews and evaluations are yet to be fully mainstreamed into governmental programming or planning processes, including through the specification of intended impacts and indicators of performance in specific sectors.

There was in addition another process for the performance assessment of local governments in Nepal. This emerged out of the idea of performance-based funding for local governments. Each local government was assessed with a set of criteria of Minimum Conditions Performance Measures (MCPM) and the results determined funding level. In the new federal set-up, however, the equalization grant is envisioned as the entitlement of the local government and will be according to "their need for expenditure and revenue capacity" 3 and hence is independent of performance level. While federal or provincial governments may set "terms and conditions" to conditional grants, ${ }^{4}$ It is not yet clear if performance criteria will be anchored to it.

\section{Financial accountability}

Nepal's public financial accountability is anchored to three key institutions: Public Accounts Committee of the parliament as parliamentary oversight entity, the Auditor General as a constitutional oversight entity, and the PEFA (Public Expenditure and Financial Accountability) secretariat as executive agency. The government is pursuing reforms in the public financial management (PFM) and is currently implementing new reform program. With the new public financial management reform program (PEFA 2016) the government seeks to achieve eight outcomes (Box 1):

1. Improved budget credibility

2. Improved comprehensiveness and transparency of budget

3. Improved policy-based budgeting

4. Improved predictability and control in budget execution

5. Improved accounting, recording and reporting

6. Improved external scrutiny and audit

7. Improved human resource management and capacity development for PFM

8. Improved donor practices

Source: PEFA, 2016

Box 1: Expected outcomes for the PFM reform program, II

In view of the need to transition into federal set-up, the PEFA has been working to integrate the system to be able to achieve systemic coherence at inter-governmental scales. This has been initiated with the application of software called Sub-National Treasury Regulatory Application (STRA). It should however be noted that the Ministry of Finance anticipates some challenges while transitioning into the federal system involving local and provincial governments. With strong commitment expressed through the II PFM Reform Program, the PEFA secretariat is expected to develop needed capacity at the local governments to achieve the outcomes. In addition, a new law, "Inter-governmental fiscal arrangement Act" will be implemented from July 16, 2018 (MOLJPA 2018). The Act sets provisions on the revenue

\footnotetext{
${ }^{3}$ Intergovernmental Fiscal Arrangement Act, 2018, Article 8(1), 8(2).

${ }^{4}$ Intergovernmental Fiscal Arrangement Act, 2018, Article 9(1), 9(2).
} 
rights, revenue sharing, grants, loans, budget arrangements, public expenditures and fiscal discipline of the three levels of government in Nepal.

\section{Social accountability}

A final, yet important, approach to accountability adopted in several legislations comprises social accountability (SAcc) mechanisms. These mechanisms entail different practices, including for example, the deliberations in public hearing or public audit, or budget tracking, assessing public service (through citizen score card) (see Khadka \& Bhattarai, 2012). At the core they provide local people and beneficiaries the platforms and tools to raise their voice, seek information and assess performance of projects, initiatives, public services, or aspects of governance, management, or decision-making in public agencies. It should be noted that while a broad menu of tools is available, a number of them have been made mandatory for public agencies and local governments in particular.

\section{Emerging local government accountability relationship and the experiences}

In respect of the broad framework of government accountability outlined above, this section develops the local government accountability relationship and the current experience of local actors.

\section{Emerging framework}

Figure 2 shows an emerging structure that positions of local government in accountability relationships, within its own structure and with respect to people as well as with federal and provincial and other institutions. The local government comprises elected representatives and civil service staff who are mostly appointed from central (now federal) government as well as service provider institutions - the schools, health facilities and so on. For local governments to become accountable, it is foremost necessary all these actors and institutions anchor their accountability to the Head of the local government - the Mayor or Chairperson. Accountability relationship should be considered in this internal plurality and resultant contestation.

Field consultations reveal that the local governments comprise not a monolithic whole with a command structure, but more as a space for contestation between the elected representatives. While most local leaders expressed that they "are one when it comes to development," there are clear indications of power tussle between them. Contestations are more intense in areas such as those involving the allocation of resources. By virtue of being autonomous the local government leaders are also engaged as local politicians and it is desirable that they maintain space for dissent and opposition, such as from other political party leaders and civil society. It should be noted that local government accountability would be more conducive under political environments that are open for opposition but safeguarding against the collusive practices that plagued most local government over the past fifteen years. 
The Prospect of Accountability in Local Governance in Nepal

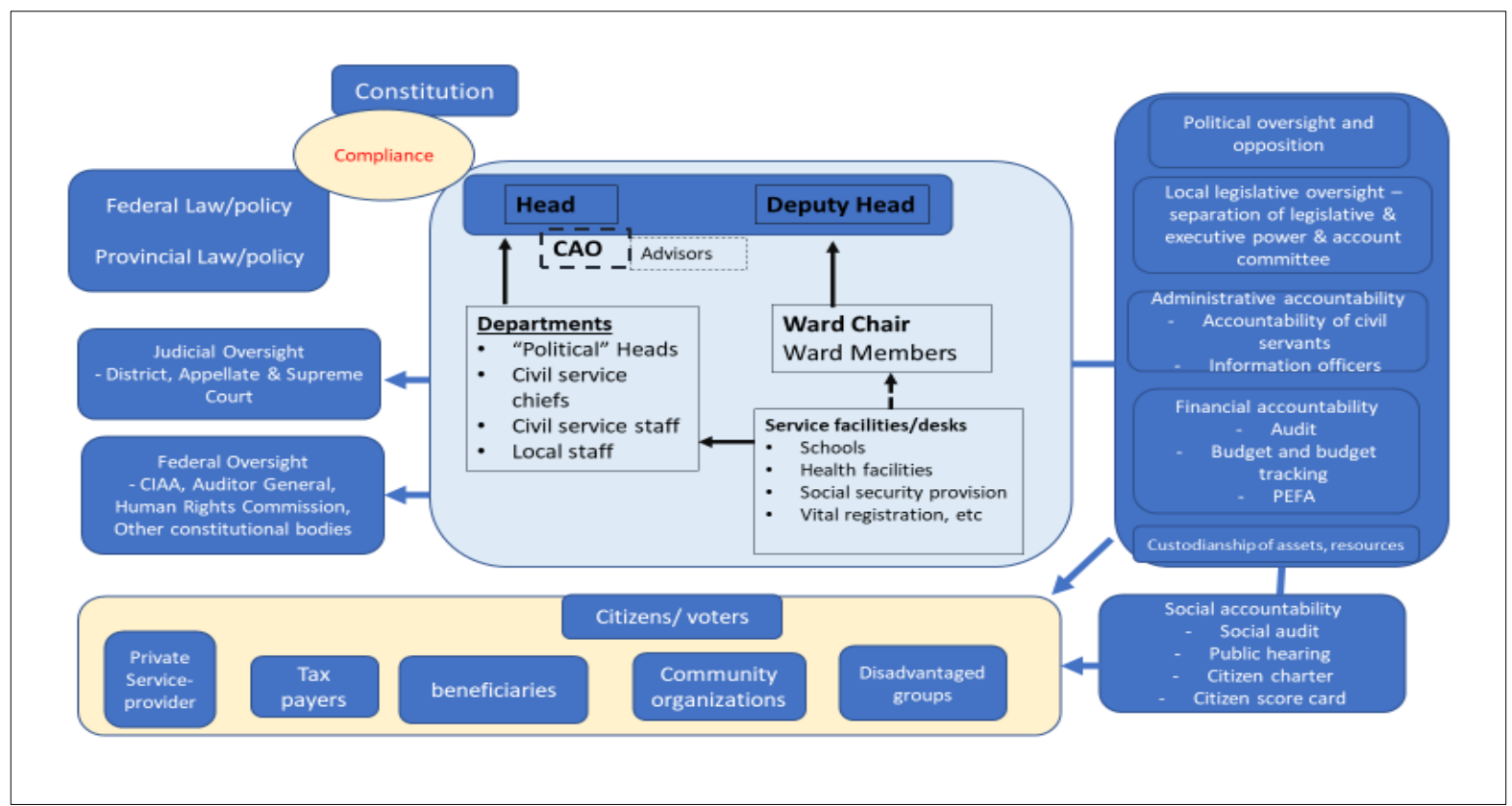

Figure 2: Accountability relationships: structure, actors and processes

It is also important to highlight that the local governments are directly accountable to the citizens or citizen groups, who in different roles and capacities (e.g. voters, tax-payers, beneficiaries, disadvantaged groups etc.). In addition to the democratic accountability through elections of local representatives in five-year intervals, local governments are positioned visà-vis the people in the following principal ways (Figure 2):

- Accountability through delegated entities (the judiciary and constitutional bodies such as CIAA, external audit from Auditor General)

- Local legislative oversight, with the provision of Local Assembly to set policies and laws and budget and direct the local executive

- Financial accountability through intergovernmental system of PEFA (see previous chapter) and with systems of internal and external audit

- The "shorter routers to accountability" -- direct interface between people and officials in the course of social accountability.

- Policy and programmatic coherence and alignment with provincial governments within the rubric of "coordination, co-existence and cooperation" that are constitutional principles shaping the inter-governmental relations.

The above postulation of accountability relationship acknowledges the autonomy of local government and emphasizes the local government as a space for exercising democracy. This should be emphasized as an important departure in local governance in Nepal, and to highlight to unique nature of Nepal's federal model.

\section{Experiences of local governments}

This section presents the local level experiences on the different elements of accountability, as were gleaned from the field consultations. Consultations show a clear willingness to foster development and achieve good governance, but differing perceptions about how to do it. 


\section{Legislative oversight and politics of opposition}

While there is clear provision of legislative functions and executive functions assigned to local assemblies and local executives, there is no provision of having local legislative oversight on the working of local government. Local level assemblies comprise mostly a mix of representatives drawn from two or three major parties or more in some other cases, constituting a government without clear sense of opposition. Municipality Mayors or Rural Municipality Chairpersons told that they mostly follow consensus as the main mode of decision-making in the local assemblies and executives. They emphasized that the executives and assemblies work primarily in collaborative spirit, but they also acknowledge that it will be important to engage local leaders who lost the elections. In regard to "legislative oversight" - very few mentioned that it may be necessary, but most others thought it can become a nuisance to development activities.

Generally, however, the constraints on Mayors largely depended upon whether he or she commands the majority members in the Assembly and in the Executive. In the five places visited, it was found that those who lost the elections have so far not been engaged in dedicated consultation as recognition of opposition party - and an overall sense is that 'we are all sattapakchhya, or on the government side" yet there is internal opposition voice. In one of the five places we consulted, an Advisory Committee of local intellectuals (ganya-manya) has been formed, but that seemed to be more symbolic than political. These consultations signal a need toward less of structural constraints on the local executive, which could be addressed through more transparency, dialogue and citizen engagement.

\section{Administrative systems and internal control}

Internal control system in the local government evolved from the existing centralized legal provisions, but local governments mostly faced the acute shortage of human resource to be able to perform even their regular service. During our consultation, we found most of Mayors/Chairpersons and Ward chairs concerned about the posting of chief administrative officer, Accounts Officer, and in the Ward level the Ward secretary. In two of the five places visited, they could not issue cheques for some months due to unavailability of either the CAO or the Accounts Officer, with pending payments on completed projects. Several of wards did not have ward secretaries, and two or more wards were serviced by a single secretary. This snapshot indicates that the need for the Federal government to take more prompt measures on staff transfers to local governments.

\section{Financial accountability}

Local governments have switched into the new audit requirements. In the past, local bodies were authorized to nominate their external auditors on their own. But, in the new set up, local government has to carry out two audits - one internal by nomination from local assembly, and one external one through auditor general. In addition, local accounts are also integrated into the PEFA system, which require further training to accounts staff and a good internet connectivity to fully streamline into the SUTTRA software.

It should also be highlighted that the accounts /administrative staff indicated the need to review public procurement process, especially in favor of achieving efficiency in the 
execution of development project. It would probably require an inter-governmental "political" understanding about specifying the ceilings for projects that should be executed through contractors or user groups.

\section{Reporting and disclosures}

According to Good Governance Act 2007 (Article 41), local governments should produce annual reports within 15 days of the completion of a fiscal year. But there has so far been no capacity or will to produce annual report so far, but the local leaders expressed the need to make annual reporting an important tool of transparency and accountability. Due to the change in the nature of local government, the provision on local government reporting needs to be updated. We propose in next sections what new elements will be useful and how this can be harmonized into planning process.

\section{Transparency, RTI and corruption control}

With over half years of the election of local government, some cases have come up in which local leaders as well as officials have been subjected to public oversight agencies, or to the test of existing laws on transparency and corruption control. A couple of cases highlights how more civic consciousness could help local government transparency and discourage corruption/rentseeking. For instance, a journalist took recourse to the Right to Information (RTI) Act to demand transparency from one of the municipalities we visited, and the publicity of that information helped create pressure for making corrections on the decision (Box 2).

A local journalist in a Municipality learned from his contacts within the administration that the elected officials made a decision in the assembly for the determination of salaries in August 2017. The salaries were set for the Mayor, Deputy Mayor, Ward Chairs and ward members. The officials took salaries for few months. But the journalist was not convinced why the decision was not made public.

He filed a Right to Information (RTI) case in the Municipality demanding information and transparency about the decision on salary. The journalist was required to follow most of the procedures of the RTI Act, as there was considerable hesitation to publicize the decision for some weeks. Finally, with the threat of taking recourse to National Information Commission, the journalist was able to receive the information regarding that decision.

While the information provided as still not comprehensive, according to the journalist, he now feels satisfied that the Municipality was forced to "postpone" the implementation of that decision after a few months

Source: interview with a journalist, Dang.

Box 2: RTI filing as a mechanism for local government transparency

Similarly, creating greater civic awareness against bribing and corruption help reduce corruption in local governments. In one of the municipalities we visited, a sub-engineer was caught-red -handed with taking a bribe from a local person, who approached the staff for getting approval of construction design for their house. The CIAA office was informed about the demand made by the staff, and the police came to capture the staff in collaboration with the beneficiary individual. There have been other cases reported in the media that some local 
people report to CIAA when demands for bribe are made by government staff. Thus, more efforts at creating civic awareness against corruption would improve government integrity.

\section{Budget allocations and fairness/equity}

Local consultations in all our five places reveal that budget allocations from the local governments are distributed more or less equally across the Wards. This was perhaps a politically easy option, but in one case funds were set aside for "municipality-level project" and "ward-level projects" and setting responsibilities and accountabilities accordingly. The implication of this arrangement is that equal distribution of funds was made only for "wardlevel projects," while retaining funds for larger scale projects according to some plan. In another instance, it was also noted that while broadly within the frame of equality between wards, some wards were given more funds, in consideration of their difficult geography and lack of development compared to other areas of the municipality.

One important change noticed in our consultation is that budget allocation for "targeted groups" 5 has discontinued at least in the jurisdictions we visited. There was an overwhelming sense of priority among local leaders for carrying out development. But in particular cases, as the consultation meeting in Sunkoshi Gaupalika showed, local governments are keen to provide support to needy households in education and, by implication, in enhancing access to other public goods. This would probably require more local deliberation about the entitlement of disadvantaged groups and what kind of support may be offered from the local government.

\section{Performance review and monitoring/evaluation}

It should be highlighted that there is no clear, coherent national strategy for conducting performance reviews across sectoral areas. While the assessment of learning achievement under the ERO is a good beginning, it has not been coherently adopted across scale and time. It can be surmised that performance reviews may become very important evidence for important development goals and policies. A framework will be needed how such evidence feeds into setting priorities and plans, if such reviews will evolve more coherently across sectors. The institutions doing that should also be credible and independent, so that the government's at all three levels have their trust in such evidence.

Furthermore, it will be useful to have a monitoring and evaluation policy at the local level. The current provision of having deputy head to monitor local government activities provides a basis for monitoring of progress, but in due course evaluating programs/projects will offer good insights for planning.

\section{Social accountability tools}

Many local government leaders have had prior experience of engaging in public hearing or public audit process, while some did not have exposure or participation in these processes. Accordingly, there is no equal level of appreciation of the need of using social accountability

\footnotetext{
${ }^{5}$ This started nationally from the policy adopted since the tenth plan (2002-2007), involving allocation of certain percentage of local government budget to women, Dalits, and janajati groups.
} 
mechanisms as opportunities for state-citizen relationship and the virtues and instrumental benefits that come with it.

It is noteworthy that local governments have citizen charters, have their own websites (some under development). It was noted that in most cases, local governments adopt public hearing or public audit for specific development project (e.g. road project). They did not hold $\mathrm{p}$ not hold public consultation, except for Waling municipality, for local government as a whole. Waling adopted "town hall" meeting, which is envisioned as a semi-annual practice. One village municipality (Sunkoshi), on the other hand, held a broad stakeholder consultation on the educational policy and manual. ${ }^{6}$ There was however agreement amongst local leaders that this was an important and necessary process for local government accountability. Accordingly, these practices could be promoted across other local governments.

\section{Discussion: challenges for local government accountability}

This article established above the accountability relationship and outlined the local experiences of enacting that relationship in the first two years of the establishment of elected local leadership. Below it identifies a number of important challenges to local government accountability in Nepal. These challenges concern with political-legal clarity on the accountability relationships for the local government vis-à-vis the people and other state institutions, "political" competency for issuing accountability approaches, developing useful lessons from the experience of the earlier accountability policies and measures, and securing local ownership and capacity for the practice and culture of accountability at the local level.

First and foremost, there is yet no clear explication from the existing policy and legal framework about the full range of accountability relationships in which local governments are politically positioned vis-à-vis their electorate as well as provincial and federal governments and the public oversight agencies. The new constitution has envisaged local government units as largely autonomous entities, especially for the functions enumerated in Schedule 8 of the constitution, and are envisioned to stand along with other local, provincial and federal governments according to the principles of cooperation, co-existence and coordination. As a legacy of centralized rule in the country and as local capacity is yet to consolidate enough to serve constitutional obligations, elected leaders and civil service personnel are just beginning to come to terms with how they are expected to operate under the new constitution. As their capacities evolve, they would seek greater autonomy in regard to laws or other provisions prescribed from provincial and federal government. Therefore, accountability relationships should be understood politically on the basis of the constitution, even though a temptation to take recourse to the implementation of existing laws is more apparent. Such a political understanding should acknowledge the possibility that local governments may resist, ignore or challenge one or the other legal or policy prescriptions from other levels of government. Accordingly, it is necessary to map and articulate the accountability relationship of local

\footnotetext{
6 The content of the consultation document presented was that of an Act, but the Rural Municipality avoided framing as such due to the constitutional limitation. The constitution postulates that local assemblies may make laws according to procedures set by provincial legislature, but such a law was not developed when the Sunkoshi consultation was held.
} 
governments in light of the constitution and new laws, and in view of the autonomous powers that local governments have.

Second challenge, closely related to the first, concerns with the competency for the issuing of legal and policy approaches to accountability for local governments. The constitution establishes a unique inter-governmental balance of power between three levels, by enumerating powers and jurisdictions on one hand, and establishing the principles of inter-governmental relationships on the other. However, elected local leaders have begun to express unease with the way the federal-level agencies, typically the Ministry of Federal Affairs and General Administration, issues bureaucratically-led directives which are seen as limiting or encroaching the political space of elected officials at the local level by the functionaries at the federal level. ${ }^{7}$ On top of the resistance to top-down prescriptions, it is important to highlight the uniqueness of Nepal's federal model itself.

Within the Nepalese federal model, local governments are autonomous on their own for the jurisdictions enumerated in Schedule 8. Unlike in many federal countries, such as Australia or India, Nepal's local governments are not placed under one or the other province and this fact conditions who is competent to introduce policies or laws on local government accountability. In Australia, which is a federal country, the provincial legislature prescribes the accountability framework for local government (e.g. Parliament of Western Australia 2015). In United Kingdom, which is a unitary country with devolved parliament, guidance for governance and accountability of Local Councils is prescribed by a panel comprising central departmental agencies, representative institutions of Local Councils and stakeholders (One Voice Wales \& Society of Local Council Clerks. 2011; JPAG 2014; 2017). These guides are applied to respective devolved nations. ${ }^{8}$ In Nepal, in contrast, past legal measures on accountability such as the Public Procurement Act, Good Governance Act, or Right to Information Act were issued with the intent of implementation at the national scale. Similarly, financial accountability for all jurisdictions in the country has been anchored to Public Expenditure and Financial Accountability (PEFA) mechanism which exists at the federal level. In sum, approaches to accountability should be considered in reference to the relative competencies of the three levels of governments, and in particular reference to local needs and contexts and with the ownership of local leaders.

Thirdly, while local governments in Nepal with vastly expanded jurisdiction under the new constitution will face greater demands for accountability, there is a need to properly draw lessons from the past accountability policies and measures. There are important differences of the local bodies under previous constitution and the local government under the new one. For instance, for fifteen years, the local bodies existed in the vacuum of elected leadership and largely under conditions of political violence and uncertainty. It has been noted that local bodies without regard to accountability on one hand, and with widespread collusion on the other (TAF 2012). In many local bodies, the government staff were mostly absent or very infrequently available, creating a huge disconnect between the state and citizens. During this

\footnotetext{
${ }^{7}$ Presentation of Ashok Byanju, Mayor of Dhulikhel Municipality (and chair of Municipal Association of Nepal) at Staff College.

${ }^{8}$ In the context of UK, the "national" represents what otherwise may be conceived as sub-national and include the nations of Scotland, Wales, Northern Ireland and England.
} 
period, legally prescribed accountability mechanisms were ignored or adopted in less effective manner, such as by developing fake papers about public audit in some contexts, as no local leader was held accountable for such deeds. In addition to these jurisdictional and contextual differences, it will be important to identify what accountability measures worked in the past and what will be potentially relevant into the new context.

Finally, a further challenge for local government accountability is to capitalize on broad political commitments in order for securing local leaders' ownership and appreciation of accountability measures at the local level. As is apparent, the idea of accountability implies constraining the power of public officials and more demands on their personal and institutional integrity. Many elected leaders, who engage in construction contracts for example, may feel tempted to use their power for favorable treatment to themselves or their close affiliates (or, afno manchhe). Even with broad political commitments for good governance and accountability, elected leaders - especially those who did not have previous experience or exposure to local government decision-making - are unaware of how accountability systems actually work in practice. engage in the former set-up the design of new accountability framework and tools. Many local leaders are struggling with running the offices, as civil service staff are not yet posted, or transferred very early. Thus, securing ownership and appreciation of elected leaders and administrative capacity to service demands for accountability remains a huge challenge.

\section{Conclusion}

The analysis in this article reveals that a commitment to accountability and transparency makes demands on local government officials - both elected leaders and civil service personnel. Indeed, accountability is a perpetual struggle when power is delegated by the many to the few in the interests of governability (Goez and Jenkins, 2005: p.1). That apparently demands a wider, national-scale push to really achieve greater momentum in this regard. Accountability in local government does not exist in vacuum (Pandey 2017) but requires a society-wide value reorientation and system development, requiring harmonization of good governance frameworks, processes, and tools. While "integrity islands" are attempted in some civil society initiatives in the past (Khadka and Bhattarai 2012), creating broader impact will require working at multiple scales and all three levels of the Nepali state.

Thus, accountability should be integrated with the processes of planning and implementation so as to enable that outcome would provide evidence for action. We particularly emphasize annual "progress" disclosures, financial statements, and periodic performance assessment statements. These statements will have to be anchored to relevant national -level institutions on one hand and communicated and explained to the electorate's $o$ the other.

There are a combination of processes and tools already in place in Nepal, but they beg the question of how they work and whether existing institutions are credible. This article argues the case for additional efforts to restore the credibility and public trust in the court and constitutional oversight agencies. Over time, these institutions should be able to establish the trust that they treat fairly and justly to all levels of government. More work will be needed to develop and institutionalize a coherent and credible basis for performance reviews and 
evaluation and subsequently use the learning and feed back into the planning and policymaking of local, provincial and federal governments. In addition to expert-led reviews, local assessments may need to be promoted by developing capacity for developing local standards and setting processes.

Finally, the government should emphasize transparency mechanisms and local level deliberations as key pillars of exercising local government accountability. Efforts should build upon the incentives for local leaders to engage with diverse local constituencies. These practices would help deepen and strengthen democracy.

\section{References}

Bhattarai, K. D. (2015). Constitution promulgated, Kathmandu Post, Sep 21. Available online:http://kathmandupost.ekantipur.com/news/2015-09-21/constitutionpromulgated.html.

Communist Party of Nepal (Unified Marxist Leninist) \& Communist Party of Nepal (Maoist Centre). (2017). Elections for the house of representatives and provincial assemblies: Joint manifesto. Kathmandu: Communist Party of Nepal (Unified Marxist Leninist) and Communist Party of Nepal (Maoist Centre).

Fischer, F. (2009). Democracy and expertise: Reorienting policy inquiry. Oxford University Press.

Goetz, A. M., \& Jenkins, R. (2005). Reinventing accountability. Making Democracy Work for Human Development. Hampshire and New York: Palgrave Macmillan.

Joint Practitioners' Advisory Group (JPAG). (2014). Governance and accountability for local councils: A practitioners' guide (England). England: JPAG.

.(2017). Governance and accountability for smaller authorities in England: A practitioners' guide to proper practices to be applied in the preparation of statutory annual accounts and governance statements. England: Joint Panel on Accounting Guidance (JPAG).

Khadka, K., \& Bhattarai, C. (2012). Source book of 21 social accountability tools. Kathmandu, Nepal: Program for Accountability in Nepal.

Kitschelt, H., \& Wilkinson, S. I. (Eds.). (2007). Patrons, clients and policies: Patterns of democratic accountability and political competition. Cambridge University Press.

Local Level Restructuring Commission. (2017). Determination of the number and boundary of rural municipality, municipality and special, protected or autonomous regions. Kathmandu: Local Level Restructuring Commission.

Ministry of Law, Justice and Parliamentary Affairs (MoLJPA). (2015). The constitution of Nepal 2015. Kathmandu: MoLJPA.

.(2017). Local government operation act 2017. Kathmandu: MoLJPA.

.(2018). Inter-governmental fiscal arrangement act 2018. Kathmandu: MoLJPA.

Nepali Congress. (2017a). Manifesto of Nepali congress: The election for House of Representatives and Provincial Assembly 2017. Kathmandu: Nepali Congress.

(2017b). Manifesto of Nepali congress: The election for local government 2017. Kathmandu: Nepali Congress.

Neupane, N. (2018, Feb 22). Government to use software to monitor local finances. Kathmandu Post. Available at http://kathmandupost.ekantipur.com/news/2018-02-22/govt-to-usesoftware-to-monitor-local-finances.html 
Niti Foundation. (2012). Policy diagnostic study peport. Kathmandu: Niti Foundation.

One Voice Wales \& Society of Local Council Clerks. (2011). Governance and accountability for local councils in Wales-A Practitioner's Guide. Wales: One Voice Wales \& Society of Local Council Clerks.

Panday, D. R. (2018). The idea of integrity and the universe of corruption and anti-corruption. Kathmandu: Redink Books.

Parliament of Western Australia. (2015). Improving local government accountability. Perth: Parliament of Western Australia, Public Accounts Committee.

Ministry of Finance. (2016). Nepal public financial management reform strategy/program (PFMRP), Phase II (2016/17-2025/26). Kathmandu: Public Expenditure and Financial Accountability Secretariat.

The Asia Foundation. (2012). Political economy of local governance in Nepal with special reference to education and health sectors. Kathmandu: The Asia Foundation.

Taylor-Robinson, M. M. (2010). Do the poor count?: Democratic institutions and accountability in a context of poverty. Penn State Press.

Thapa, H. B. (2017). Rajagaja: corruption in parties, the palace, the court and commission for the investigation of authority. Kathmandu: Fineprint.

Tsai, L. L. (2007). Accountability without democracy: Solidary groups and public goods provision in Rural China. New York: Cambridge University Press.

\section{Acknowledgements}

This article draws on materials from the work undertaken by the author with Niti Foundation, Kathmandu with the funds made available by The Asia Foundation. The author thanks Shiva Hari Adhikari, Prabhash Man Singh, Trilochan Pokharel, Mohan Das Manandhar, and Ashray Pandey for their inputs in the course of that assignment and in subsequent conversations. The opinions expressed herein, however, are those of the author and do not in any way represent views of the people and organizations named above. 